Sabine Keller and Bernhard Nauck

\title{
The German Family Panel (pairfam). Research Potential and First Results of a Multi-Disciplinary Longitudinal Study on Partnership and Family Dynamics in Germany
}

Abstract: The German Family Panel pairfam is a multidisciplinary, multi-actor, longitudinal study of partnership and family dynamics in Germany. The present paper illustrates the wide analytical potential inherent in the annually growing pairfam dataset by summarizing published analyses of pairfam data on the topics of partnership, parenthood, and intergenerational relationships. Since the panel is uniquely rich due to its longitudinal and multi-actor design, this selection of publications also provides a concise review of current developments in the sociology of family and partnership.

\section{Introduction}

The cutting edge of sociologically informed family demographics currently lies beyond the description of household composition. Sociological researchers now have the ambition to understand the long-term and interdependent dynamics of multi-local family systems. The field, however, is also increasingly informed by psychological research with its focus on the influence of mutual expectations, individual cognitions, and emotions on behaviors. Moreover, medical research is revealing an ever greater number of linkages between family life and health. Future theoretical progress in this increasingly interdisciplinary endeavor thus requires the acquisition of increasingly complex data on couple and family dynamics (Huinink et al. 2011, 78).

The German Panel Analysis of Intimate Relationships and Family Dynamics (pairfam) study was designed in cognizance of the challenges to obtaining complex data on family and relationships. Its prospective design covers panel members in multiple generations from adolescence to late adulthood, allowing study from different disciplinary perspectives of relationship dynamics and contextual conditions in the proximal and distal environment. Funded by the German Research Foundation (DFG) on a long-term basis, the pairfam project brings together researchers from multiple German universities. A total of fourteen annual waves are planned. Pairfam data are published and maintained as a collective good for the scientific community in the form of scientific use files. 
This article provides an overview of the methodological-conceptual framework of pairfam. Relevant publications based on the project's data are summarized by way of demonstrating pairfam's intended and actual contribution to the advancement of research into family and relationship dynamics. Due to the comprehensive nature of the pairfam project and the wide variety of authors that have drawn on its results, this sums to a fairly encompassing overview of current innovations and trends of research in this field generally.

Any project endeavoring to obtain complex data on family and relationship dynamics must overcome several fundamental challenges (a more detailed review is provided in Huinink et al. 2011). First, a new sophistication of descriptive statistics is necessary to account for the expanding variety of relationships and constellations characteristic of modern families. Second, research needs to include data from both respondents and their partners if the goal is to better understand mutual interdependence in decision making and action. For capturing individual perspectives on linked lives, adequate methodological approaches, including multi-actor designs and dyadic data analyses, are necessary. Third, for understanding couples and family dynamics as part of the multidimensional life course, special attention needs to be paid to cross-domain effects or the mutual influences between domains as they impinge on context-bound individual goaloriented action. Fourth, recursive selection and adaptation across the life course is a critical issue because mechanisms of self-reflecting selection and adaptation make it difficult to specify cause and effect in family relations. Finally, families are embedded in social, economic, and cultural contexts and this multilevel context and social embeddedness affect their structure and function (80).

For help in clarifying the innate complexity of family relations, pairfam makes recourse to the theoretical assumption of individual economic rationality as limited by social and cultural constraints. Although it is assumed that individuals attempt in the rule to optimize their subjective well-being over the life course, the life course itself is known to be embedded in a multi-level structure consisting of interrelated life domains (the assertion of multi-dimensionality) and is influenced by past events and decisions (the assertions of path dependency and trajectories). Moreover, future events are considered relevant for current behavior because expectations about status changes in the near future may motivate immediate life-domain changes and because actors may anticipate possible future effects in choosing current behavior. Past events are relevant because actors learn from past actions and because past choices restrict the range of action alternatives later (88).

This theoretical framework was employed to specify the information collected by the pairfam project. Of central importance are questions regarding the relevant opportunity structure impinging on choices and perceptions; for example, information about the perceived marriage market is collected to buttress inquiries into marriage intentions or partnership history. The multi-actor design allows for the analysis of processes not just from the perspective of main or 'anchor' respondents but also from their partners, parents, and children. The individual resources of anchors and alteri such as time, skill, or income are measured separately. Personal psychological dispositions are tied to motivation and 
are modeled specifically for each life domain and each phase of the life course. Similarly, intentions capture the readiness for transitions in the life course of the individual. Domain-specific utility expectations are relevant because these are connected to substitution, compensation, and complementation effects between life-domains and thus also to current subjective well-being in each life domain, which should be monitored continuously because it affects the probability of future actions (89f.).

\section{Methods, Instruments, and International Comparability}

The pairfam project, the largest study of its kind in Germany, is an annual panel survey. Fieldwork started in 2008 with more than 12,400 anchor respondents and is planned to continue through 2022. Anchors are drawn from three birth cohorts (1971-1973, 1981-1983, and 1991-1993). Their partners, parents, and children are also included in the annual survey (figure 1). Survey data, including documentation and pre-generated aggregate indicators, have been available for domestic and foreign scientists from the beginning. To date, more than 830 scientists from 25 countries have registered as pairfam users.

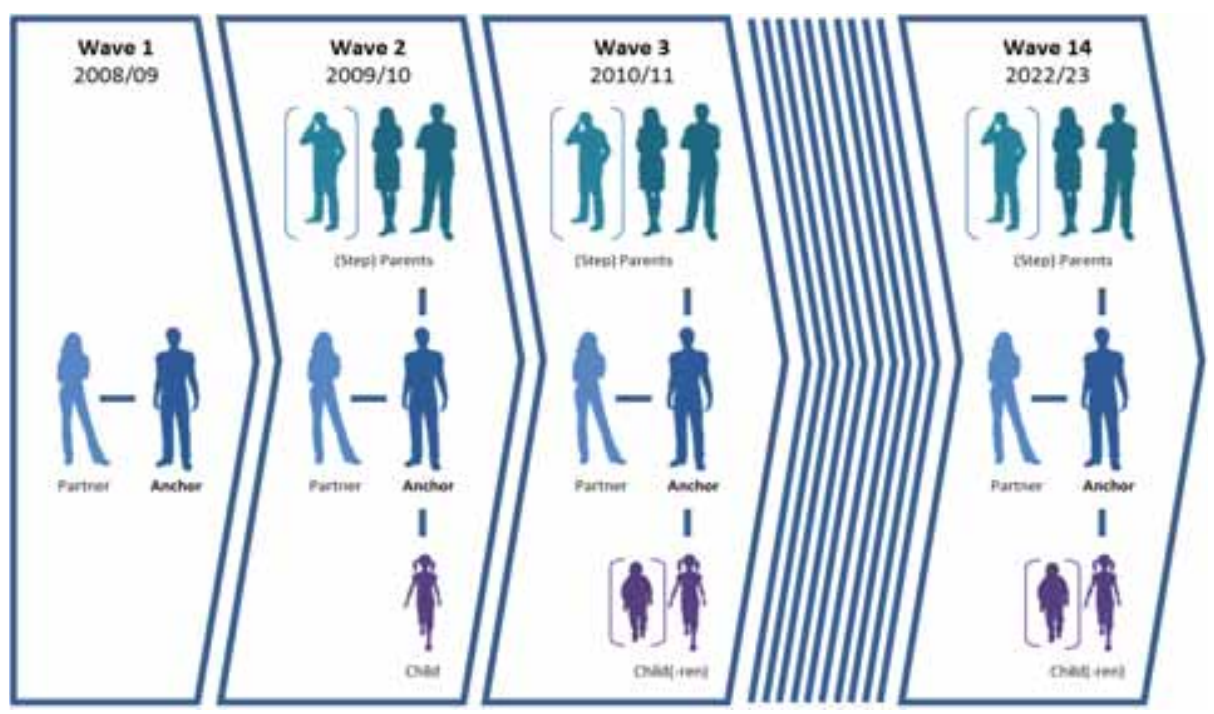

Figure 1: Multi-Actor-Design

Pairfam is linked to other national and international surveys. The panel of eastern Germans from the complementary study DemoDiff was integrated into pairfam with wave five and has already been used for several analyses (for exam- 
ple, Bastin 2012; Kreyenfeld et al. 2011a; Schnor 2012). ${ }^{1}$ Other data sets are also well suited for joint analyses: The Partner Market Survey (Häring et al. 2011), the DJI Child Care Study (Lois/Kopp 2011), the German General Social Survey (ALLBUS), the Socio-Economic Panel (SOEP) (Mühling/Schreyer 2012), Job Mobilities and Family Lives in Europe (JobMob) (Rüger et al. 2011), Process of Mate Choice in Online-Dating (PMOD), and the online panel of a German dating platform (Schmitz et al. 2011). Moreover, international comparisons have used pairfam data in combination with the Generations and Gender Survey (GGS), the Fertility and Family Survey (FFS), the International Social Survey Program (ISSP), and the British Household Panel Survey (BHPS). For instance, Nauck and Tabuchi (2012) researched the influence of education on family formation and its changes in Japan and Germany during the last 60 years. In their work, they linked the data of twelve studies including pairfam. Also Perelli-Harris et al. (2010) investigated the connection between education and fertility in Germany, Austria, France, Italy, the Netherlands, Norway, Russia, and the UK. A related study, which also included Bulgaria, Hungary, and Romania, investigated the link between fertility and family type as well as the prevalence and longevity of civil unions (Perelli-Harris et al. 2012). Kreyenfeld et al. (2011b) compared the quality and availability of official birth statistics and survey data in Germany (among others, pairfam), Austria, and Switzerland. The authors found that family-specific surveys overestimate the number of children among younger cohorts and recommend weighting data to reduce bias (349). Moreover, efforts are being made to harmonize pairfam data with that available from other survey programs such as the Netherlands Kinship Panel Study (NKPS, Netherlands), the Gender and Generation Program (GGP, 19 countries), the Panel Study of Family Dynamics (PSFD, Taiwan), the Panel Study of Income Dynamics (PSID, USA) and the Longitudinal Survey of Generations (LSoG, USA).

The most powerful analyses of pairfam data to date focus on partnership, family formation, parenthood, and intergenerational relationships. A small selection of these is presented below. Because these studies speak to only a small selection of the comprehensive range of pairfam topics (cf. figure 2 in the appendix) and relatively few scientists have been able to use data from more than two waves (Huinink/Feldhaus 2012; Lois/Lois 2012; Richter et al. 2012), we expect the scientific impact of the pairfam project to steadily increase.

\section{Partnership}

Published analyses of pairfam data cover a wide range of partnership matters. In addition to investigations of mate choice and mating markets, the institutionalization of partnerships (i.e. setting up a common household and marriage) has attracted particular interest. Also of interest have been the quality and stability of couple relationships. Data on the diversity of partnership arrangements, also in combination with parenthood, have been used in investigations of various aspects of marital and non-marital family constellations.

${ }^{1}$ http://www.pairfam.de/en/data/demodiff. 


\subsection{Mate Choice and Mating Markets}

The scientific community has recognized that online dating platforms are of increasing importance for finding partners (for example, Skopek et al. 2009). Some analyses are already based on pairfam data. Schmitz et al. (2011) looked into several prejudices, including the belief that online daters cannot find a partner by conventional means. This was not confirmed in the pairfam data (364). In a similar vein, Häring et al. (2011) examined whether an extensive search strategy - involving singles parties, dance events, and online datingoffers an alternative for people with low chances on the conventional mating market. They found that extensive search strategies were associated with success for people with otherwise limited prospects (70). Another myth is that online mating platforms are used by a negligible number of persons. In fact, Schmitz et al. (2011, 375) found that especially young cohorts increasingly choose this manner of mate choice. Further, there are no indications that online and offline partnerships differ in quality, at least in terms of articulated declarations of love or in plans to set up a common household (ibid.). Finally, results of other surveys have been confirmed by researchers using pairfam data. For example, partners in online-initiated relationships are more homogenous in age, education, and current marital status than conventional couples (376f.; Skopek et al. 2009).

\subsection{Institutionalization}

The conventional script of love, engagement, and marriage is no longer an inevitable course. People often move in together before they marry, and not every relationship ends in wedlock (Kopp et al. 2010). There is a growing tendency to start partnerships at an early age and to set up a common household soon after leaving the parental home (Konietzka/Tatjes 2012, 194). Salzburger and Walke $(2010,26)$ showed that women tend to move in with their partner much earlier than men. Western German men set up a common household with their partner quicker than their eastern German counterparts (Tatjes/Konietzka 2010, 24).

In this regard, Diener and Feldhaus (2011) investigated whether the probability of moving in together is affected by social benefit rights. This is of special interest because the formation of a common household (called a 'Bedarfsgemeinschaft' in German social welfare law) may disqualify some or all of its members from social welfare payments (200f.). Research indicated that receivers of social welfare benefits for the indigent (ALG II) are less likely to set up a common household regardless of education level, regional origin, gender, and relationship duration (215). However, controlling for several indicators of the dynamic of partnerships including partnership satisfaction and need for autonomy, the negative effect lost its statistical relevance (210). Hence, financial reasons appeared to be an obstacle to form a common household only under the condition of insufficient attachment (216).

Following Feldhaus and Schlegel (2011), a distinction needs to be drawn between moving in together and marriage. They concluded that the likelihood of setting up a common household was raised mostly by mutual feelings of love, a 
planned marriage, and financial motivations. The decision to marry, however, was mainly affected by norms, values, and the desire for children (97f.). Furthermore, men's need for autonomy negatively influenced the establishment of a joint household. Once this step has been taken, however, their need for autonomy had no noticeable remaining impact on the likelihood of a marriage (97). Mühling and Schreyer $(2012,69)$ found that western German partnerships are institutionalized sooner, which also led more often to marriage than among eastern Germans (69f.). Evidence drawn from pairfam data also supported the wellknown correlation between marriage and parenthood and confirmed the positive effect of religiosity on the likelihood to marry in eastern Germany (70).

\subsection{Partnership Satisfaction and Stability}

Partnership quality is of special interest. In happiness research it ranks first of all known factors affecting personal sense of well-being, and it also affects mental health and the stability of partnerships (Schmahl et al. 2011, 125). Schmahl and Walper (2012) investigated how the satisfaction of needs for autonomy and relatedness links to relationship satisfaction. The results confirmed that low need satisfaction affected both relationship satisfaction and stability. More precisely, the fulfillment of relatedness primarily affected satisfaction and the steps toward institutionalization whereas fulfillment of autonomy mainly affected stability (383f.). Moreover, the need satisfaction of both partners was relevant, although that of women carried more weight. Additionally, men, who have a higher need for autonomy and more often feel restricted, remained more frequently in a less satisfying relationship than women (382). With increasing education, the satisfaction of autonomy was more likely, but the satisfaction of autonomy and relatedness decreased the longer the relationship had lasted (ibid.).

Arránz Becker (2012) inquired into how life goals, values, personality, and personality differences between partners influence relationship satisfaction and stability. High orientation toward marriage, family solidarity, and religiousness were found to have a positive influence on satisfaction. However, if partners differed in terms of family solidarity, gender role orientations, life goals, the desire to have children, or the orientation toward marriage, both satisfaction and the stability were affected negatively. Differences in religiousness seemed to have no significant influence (10f.). A closer look at personality showed that self-esteem as well as emotional autonomy, in contrast to social inhibition and irritability, generally affected the partnership and its future prospects positively. This was particularly true for the respondent's personality, although their partner's personality was not unimportant. Referring to gender-role orientations, partnerships with more traditional female partners were associated with higher satisfaction and stability, whereas traditional male partners were more likely to have less satisfying relationships (ibid.).

Rainer and Smith (2012) concentrated on the satisfaction of sexual needs. In particular, they emphasized the influence of communication. They showed that listening and asking questions when in disagreement influenced sexual satisfac- 
tion positively (590f.). Women and the more highly educated favored a higher information acquisition effort, which then had a positive impact on sexual satisfaction as well (591).

Schmahl et al. (2011) focused on the destabilization and dissolution of partnerships. They investigated the extent to which the fear of commitment, ambivalence, frequency of conflicts, and a negative conflict style destabilize relationships directly and indirectly. For Schnor (2012), the influence of religiousness on dissolutions in eastern and western Germany was of key interest. The most fragile partnerships were nondenominational partnerships, regardless of whether these involved a marriage certificate or not, and civil unions of Catholics (250). Schnor showed that non-church affiliated eastern Germans differ from western Germans only marginally. However, eastern German church members are distinguished by a considerably lower likelihood of dissolution (248).

Another potential destabilizer, the influence of employment status and education on unfaithfulness, was addressed by Smith (2012). In general, the prevalence of extramarital relationships increased with socio-economic status. This may be explained by the fact that higher-status persons may have more opportunitiesduring business trips for example-for initiating new relationships or because they may be more attractive to potential new partners. At the same time, however, tertiary education was found to decrease the risk of unfaithfulness due to an increased awareness of possible negative consequences (338).

\subsection{Bilocal Partnerships}

Due to increased individualization and occupational mobility, a growth of partnerships in separated households is expected. Currently about 10 percent of persons 18 years or older do not share a common household with their partner, a number that is trending upward (Asendorpf 2008). What characterizes these persons and relationships? Lois and Lois (2012) investigated couples in the family-intensive period who do not share a common household, examining the durability of "living apart together" (LAT) relationships of persons born in the years 1971 to 1973 and 1981 to 1983 . The authors linked visions of partnership with occupational circumstances to differentiate between different types of LAT (131). They found out that relationships based on the vision of autonomy and independency, the so-called "ideal LAT type", was characterized by a high need for autonomy, a low likelihood of moving in together, and a high risk of separation (135f.). Persons who lived in distance relationships due to occupational reasons ("mobile careerists") tended to have a high socio-economic status. Contrary to previous assumptions, no decisive disadvantage regarding satisfaction and stability relative to the ideal type could be detected. Furthermore, persons in this type of LAT moved in together more often than expected and had a low risk of breaking up (136). Partnerships that united persons of lower socio-economic status and satisfaction level in the "economically disadvantaged" LAT type were associated with the highest likelihood of breaking up and the lowest likelihood of creating a common household (ibid.). The cluster analysis of Lois (2012) took three age groups into account and distinguished between the following six 
types of LAT: consolidated youth partnerships, uncommitted youth partnerships, occupationally integrated harmonious LATs, distance relationships due to occupational reasons, biographical restricted LATs, and conflict-prone LATs (257ff.). Also investigated were rates of moving in together and of breaking up (261). Irrespective of the particular type, just under two thirds of LAT couples remained in their bilocal partnerships over a period of 12 months. The types only differed in their rate of transitions. Youth partners more frequently tended to separate than to move in together. The other four groups were more or less inclined to bring their households together (ibid.).

Dorbritz and Naderi (2012) focused on the stability of bilocal partnerships generally. They found various differences between the birth cohorts of 1971 to 1973 and 1981 to 1983 . For the older cohort only, the occupational activity of both partners reduced, whereas homogenous education raised the likelihood of setting up a common household. Those of the younger cohort who had had a higher number of previous cohabitation relationships were less likely to move in together. Furthermore, the verbalization of the intention either to separate or to set up a common household was associated with a higher chance in both cohorts that the intended event later occurred (459f.).

\subsection{Types of Partnerships and Parenthood}

Feldhaus and Huinink (2011) pointed out that it is no longer sufficient to consider only the traditional family that permanently shares a common household (100). There is an ongoing diversification of lifestyles and unconventional family types, including single parents, stepfamilies, and patchwork families, and these are becoming increasingly stable (101).

Bastin (2012) focused on women who do not share a common household with a partner while entering motherhood. Like Kreyenfeld and Bastin (2010, 28) she found that women who do not have a partner in the household were not necessarily single. Merely six percent of western German and eleven percent of eastern German mothers were true singles when they gave birth to their first child. Additionally, Bastin $(2012,142)$ found that more eastern German than western German mothers broke up with their partners before childbirth. In the first five years after childbirth, LAT mothers experienced more partnership changes and dissolutions than mothers who had been true singles at the time of childbirth (Bastin et al. 2012, 221f.). The likelihood of being financially independent of a partner due to sufficient education decreased the likelihood of moving in together for LAT parents, whereas it increased the likelihood for initially single mothers (Bastin 2012, 223).

Lois and Kopp (2011) examined whether children of single parents facilitate or obstruct a new partnership and to what extent they influence the propensity to separate or to set up a common household. The results indicated that children slowed down the initiation of new partnerships. However, once a partner is present, children stabilized the relationship by increasing the likelihood of setting up a common household and decreasing the likelihood of dissolution (69f.). 
Looking at types of partnerships, especially those after family formation, civil unions are already a well-established part of living together in eastern Germany. In western Germany, civil unions, LAT partnerships, and single parenthood are gradually making inroads into the monopoly of marriage. Western German civil unions with children are more fragile than among eastern Germans (Bastin et al. 2012, 142f.), but in both parts of Germany, more people are living permanently in civil union (143).

Finally, Buhr and Huinink (2011) examined the occurrence of poverty, loneliness, and dejectedness among different household types. The results emphasize that young single men, parents of the same age, and single parents were more often affected by income poverty. Furthermore, not parenthood but the presence of a partner served most to reduce loneliness and dejectedness (224).

\section{Family Formation and Parenthood}

Taking shrinking birthrates into consideration, analyses of family formation, family extension, and parenthood are more than ever of high interest. Publications based on pairfam data mainly examined the desire for children and the realization of plans for having children. Some initial analyses on the influence of life satisfaction have also been conducted.

\subsection{Desire for Children}

Asking couples about their desire for children is one of the few ways to gain insight into fertility behavior before the end of the fertile phase. Whether behavioral intentions can be studied empirically at all is controversial (see, for example, Ruckdeschel 2004, 364). Buhr and Kuhnt (2012) inquired into the stability of the desire for children, seeking determinants of opinion changes. The analyses revealed that fertility plans in general tend to be fairly instable, even over a 12-month period: 61 percent of eastern Germans and 64 percent of western Germans showed no shift of opinion between the first and second waves (286). The reconsiderations were mainly caused by family events such as the establishment of a new partnership or the dissolution of the current one. Occupational changes like the onset or ending of unemployment did not have comparable effects (290). However, it might be reasonably assumed that age, gender, and current parenthood influence the stability of the desire for children such that the desire for children is more stable for some groups.

Kotte and Ludwig (2011) focused on the influence of the transmission and contagion of fertility intentions and on the realization of stated intentions. The number of own siblings and the parenthood of friends positively influenced the desire for children. Nieces and nephews raised slightly the desire for own children but tended to reduce its realization (224). Furthermore, attitudes among social contacts about respondents' fertility intentions were found to be influential. Parents and friends of respondents planning a birth within the next two 
years tended to be similar in terms of their approval or disapproval of the intention (Dorbritz/Manthe 2012, 13f.).

Fertility plans are also affected by particular circumstances. Buhr and Huinink (2012) discovered that family policy arrangements that help to reconcile work and family life had a positive influence on the desire for children. This was particularly true for women, childless persons, and the highly educated. Financial support had little overall impact, although its influence was higher for the less well educated and those with lower incomes. In general, financial support, including the parental allowance (Elterngeld), seemed to be less effectual (337). However, arrangements that come into effect immediately were more important than benefits incurred later such as all-day schools or pension bonuses (328). The relevance of family policy was shown by the finding that just under three-fourths of respondents stated that their decision to have a(nother) child depended on such arrangements (327). Moreover, 40 percent of those who actually completed their family planning would have reconsidered having a(nother) child if family policy better suited their needs (337).

Notwithstanding these findings, the partnership seemed to be at least as important as family policy. Thus, Dorbritz and Manthe $(2012,13 \mathrm{f}$.) pointed out that the desire for children was stronger in relationships with a marriage certificate and with a common household. In general, the likelihood of preferring childlessness is higher for singles and bilocal partners (ibid.). Furthermore, Huinink and Feldhaus (2012) examined the influence of commuting behavior on fertility plans and their realization. They found that the commuting distance had no effect on the intention of having children within the next two years, but commuting behavior had a negative effect on the actual realization of fertility intentions for women. Men were only affected for a short period right after the commuting started (511f.).

Partnership quality seems to have an important influence on the desire for children as well. According to Hillmann (2012, 120), parents were more likely to want to have another child within the next two years if they are satisfied with their relationship. It is no surprise that thoughts of separation and negative interaction might prove to be a hindrance. Also, partners generally shared opinions on family formation and family extension, especially partners who already had children (ibid.).

Hutteman et al. (2012) analyzed the influence of personality (measured as self-esteem, shyness, and aggressiveness) of both partners on positive and negative expectations toward parenthood as well as their influence on fertility intentions and outcomes one year later. Whereas self-esteem increased positive parenthood expectations, shyness and aggressiveness raised negative associations (6f.). The lower the negative expectations, the higher was the likelihood of desired parenthood within the next two years. In contrast, positive associations with having children showed no influence (7). Regardless of gender, the likelihood of founding a family increased with the intention to do so, but family extensions were mainly influenced by female intentions (7f.). Finally, the authors found only a minor influence of personality on actual childbirth. Thus, self-esteem had a marginal effect on family formation and none on fam- 
ily extension. There was no effect at all for shyness, and aggressiveness had a low predictive value. Aggressiveness merely decreased the likelihood of the first childbirth for men (8).

\subsection{Family Formation and Family Extension}

The social patterns that determine family formation and family extensions are not fully explained (Bauer/Kneip 2011), but partnership, religiosity, and regional origin have been discussed. Bauer and Kneip (2011; 2012) explored fertility from the partnership perspective and ascertained that neither men nor women per se have a higher influence on procreative behavior. Only those partners who possess a considerably higher degree of bargaining power were able to disregard their partner's desire for children (Bauer/Kneip 2011, 245). Additionally, women tried to achieve their goals within the relationship, whereas male partnersgiven the appropriate power constellation - preferred a new partnership (250). Usually, different opinions arose from indecisiveness, not from opposing positions (Bauer/Kneip 2012, 544).

The legal status of the relationship was shown to be important as well. Beside the distinctly lower age of first birth, the higher rate of births out of wedlock in eastern Germany is well documented (Kreyenfeld et al. 2011a, 171). However, the rate of conception out of wedlock in western Germany is increasing. Most western German partners but fewer eastern German partners married before the birth of a child, a difference that is not totally explained by the fact that the religiosity of the female partner decreased the likelihood of birth out of wedlock (171f.).

Buhr et al. (2011) explored east-west differences and tried to find causes for different fertility patterns, focusing on financial stability, availability of child care, and the reconcilability of family and work life. Their analyses illustrate that family formation and family extension need to be distinguished. While for western German women, all three indicators showed a significant influence on the birth of the first and second child, eastern German women showed different patterns. As soon as they had financial security and flexible child care, the intention to found a family in the foreseeable future increased. The reconcilability of family and work life seemed to have no effect. Concerning the second childbirth, none of the three indicators proved to be relevant (190). However, Richter et al. (2012) investigated the influence of social pressure, support, and contagion of the social network on family formation and family extension. They found only marginal effects for the first childbirth but substantial effects for following ones. It appeared that only social pressure had an influence on family formation, and its influence was low. In terms of family extension, all three determinants had a considerable influence on the birth of every following sibling (113). The authors also examined east-west differences and ascertained that western German parents felt more social pressure, whereas eastern Germans perceived more social support. However, this difference was apparently without consequences, despite the fact that social pressure and contagion influenced eastern Germans more than western Germans in actual behavior (114). 
Hubert (2011) investigated the influence of religiosity. Both church membership as well as church attendance had a positive effect on the expected number of children. Protestants and Catholics did not differ. Muslims were less likely to be childless and more likely to have many children. A church wedding had no independent influence, but marriage in general had a positive impact on the expected number of children (222).

\subsection{Life Satisfaction}

Transitions into parenthood as well as family extensions are always associated with a change of living conditions. These can have a positive and a negative impact on life satisfaction (Nomaguchi/Milkie 2003). Pollmann-Schult (2013) searched the first pairfam wave for a connection linking parenthood with subjective well-being and general life satisfaction. In contrast to childless individuals, mothers and fathers tended to be less satisfied with their leisure time, social contacts, and their partnership. However, parenthood had a positive influence on general life satisfaction independent of income. This was apparent only for parents with children four years old or younger (92ff.). The employment activities of the partners seemed to have no influence on males' life satisfaction, but full-time employed childless women were significantly less satisfied than unemployed or part-time employed mothers (95). Finally, Pollmann-Schult took parenthood status into account. Childless men and women were considerably less satisfied with their lives than were stepparents and biological parents (97).

\section{Intergenerational Relationships}

Intergenerational relations have increased in importance due to increasing life expectancy and the corresponding increase in time spent with children and grandchildren. Moreover, the increased prevalence of step- and patchwork families (Feldhaus/Huinink 2011, 100) raises new questions about their effects on intergenerational relationships.

\subsection{Parent-Child-Relationship in Stepfamilies}

Even though stepparenthood is not a phenomenon of modern times, the reasons for it have radically changed over the past century. Widowhood was replaced by separation and divorce as the main reason for non-biological parenthood. Almost 14 percent of children under the age of 18 live in stepfamilies (Steinbach 2008). Arránz Becker et al. (2013) investigated the relationship between parents and their (step-)children. Their design, which looked at relationships with multiple children and stepchildren of a single respondent, facilitated causal inference (1144). The analysis showed that stepparents' relationships to their stepchildren were considerably less close than that of biological parents to their own children (1143). This so-called "stepgap" was more conspicuous for mothers than for fathers. The results also showed that parents felt closer to biological children of 
the current partner than of previous partners (1143f.). The stepgap was reduced by the presence of approving family norms, marriage, and the increased duration of the stepparent relationship. All these factors positively influenced the degree of closeness (1144).

Klaus et al. (2012) examined the development of the relationship to biological and stepfathers after leaving parental home. The authors found that daughters were more likely than sons to neglect the relationship to both fathers. The closer relationship to the stepfather for both sexes was due to the shared household and the more convenient opportunity structure (166). However, the relationship to both fathers tended to be reserved and weak and to remain that way among children who had left the parental home (ibid.).

\subsection{Intergenerational Relationships of Migrants}

The "solidarity thesis" asserts that the migration experience imparts a higher degree of emotional closeness to children and parents of migrant families. The contrasting "conflict thesis" assumes rather that migration break families apart (Baykara-Krumme et al. 2011b, 261ff.). With the help of multivariate analyses, Baykara-Krumme et al. (2011a; 2011b) tested the two theses among migrant families; they examined emotional closeness and frequency of conflicts to parents in Germany among native Germans, Turkish immigrants, and immigrants of German ethnicity. Native Germans and immigrants of German ethnicity differed only marginally in terms of emotional closeness to their parents, whereas respondents with Turkish roots had a considerably higher level of closeness. Differences remained even under consideration of geographic distance, attitudes, and socio-demographic factors (Baykara-Krumme et al. 2011a, 48; 2011b, 275). This was not the case for the frequency of conflicts. Migrants less often indicated conflicts with their parents. Under consideration of geographical distance, number of siblings, and selected values (such as familialism and religiosity), differences between respondents of Turkish descent and native Germans was eliminated altogether and differences among ethnic German immigrants and natives were minimized considerably (Baykara-Krumme et al. 2011a, 47; 2011b, 272). In sum, the results tended to support the solidarity thesis (Baykara-Krumme et al. 2011a, 48; 2011b,278).

\subsection{Grandparents and Grandchildren}

Because extended grandparenthood is a more recent phenomenon, little research has been conducted on relationships between grandparents and grandchildren (Uhlendorff 2003). Arránz Becker and Steinbach (2012) inquired into factors that have an impact on these relationships and discovered that neither geographical distance, grandparents' employment, grandchildren's number and gender, religiousness, parents' familialism, nor the grandfather's health status were of vital importance. In contrast, the relationship between parents and grandparents, grandparents' attitudes toward mutual support, the presence of both grandparents as well as the grandmother's health status - as the grandmother 
in general has a closer relationship to the grandchildren-were decisive. Finally, grandchildren from eastern Germany had a more intimate relationship to their grandparents than their counterparts from western Germany (556f.).

\section{Prospects for Future Research}

Data from the first four pairfam waves have been available to the scientific community since mid-2013. With the publication of wave four, the analytical potential of the data set increased greatly. Several authors of previous articles have emphasized the need to verify early results with longitudinal data (e.g. Dorbritz/Naderi 2012; Feldhaus/Schlegel 2011; Hutteman et al. 2012; Lois 2012; Pollmann-Schult 2013). There is also much room for research into new questions. All three main pairfam topics (cf. figure 2 in the appendix) are far from being exhausted. The pairfam questionnaire provides instruments for analyzing the value of partnership, role allocation, sexuality, stressors, cognitive-emotional dispositions, and adaptive processes. Furthermore, publications on parenthood based on pairfam data have to date used only a fraction of the total information available. Due to the still small number of cases, transitions into (multiple) parenthood have been difficult to investigate, especially in the younger cohorts. By completing and releasing new survey waves, the number of these cases continues to grow. Additionally, as they finish their fertile phase, data from the oldest cohort enhances the project's analytical potential by providing the chance to examine the final number of children as well. Better insight into intergenerational relationships, too, should be possible as the timespan of the panel increases. Hence, the likelihood for a sufficient number of relevant events such as moving out of the parental home, family formation, and need for care rises with each new wave. Up to now, the impact of events on relationships has received special interest. In the future, questions regarding how intergenerational relations influence the occurrence of events like family formation can be investigated to greater effect.

Although previous analyses have already covered a broad range of topics and methods, plenty of opportunity remains for subsequent researchers to exploit the data set in areas that have yet to be illuminated. Upcoming waves increase the range of content with the addition of new modules (e.g. about siblings in wave 5 ). Moreover, almost 95 percent of the authors of hitherto published analyses had only the first two waves at their disposal. By taking more waves into account, later studies will obtain greater explanatory power. 


\section{Bibliography}

Arránz Becker, O. (2012), Effects of Similarity of Life Goals, Values, and Personality on Relationship Satisfaction and Stability: Findings from a Two-Wave Panel Study, in: Personal Relationships, Early View, 21 Sep 2012), 1-19

-/V. Salzburger/N. Lois/B. Nauck (2013), What Narrows the Stepgap? Closeness Between Parents and Adult (Step)children in Germany, in: Journal of Marriage and Family 75, 1130-1148

- A. Steinbach (2012), Relations between Grandparents and Grandchildren in the Context of the Family System, in: Zeitschrift für Bevölkerungswissenschaft 37, 543566

Asendorpf, J. B. (2008), Living Apart Together: Alters- und Kohortenabhängigkeit einer heterogenen Lebensform, in: Kölner Zeitschrift für Soziologie und Sozialpsychologie 60, 749-764

Bastin, S. (2012), Dynamik alleinerziehender Mutterschaft. Partnerschaftsverläufe in der frühen Elternbiografie, in: Huinink, J./M. Kreyenfeld/H. Trappe (Hg.), Familie und Partnerschaft in Ost- und Westdeutschland. Ähnlich und doch immer noch anders, Leverkusen, 201-228

—/M. Kreyenfeld/C. Schnor (2012), Diversität von Familienformen in Ost- und Westdeutschland, in: Krüger, D./H. Herma/A. Schierbaum/D. C. Krüger (Hg.), Familie(n) heute. Entwicklungen, Kontroversen, Prognosen, Wiesbaden, 126-145

Bauer, G./T. Kneip (2011), Familiengründung und -erweiterung als partnerschaftliche Entscheidung. Ein Test konkurrierender Entscheidungsregeln, in: Brüderl, J./L. Castiglioni/N. Schumann (Hg.), Partnerschaft, Fertilität und intergenerationale Beziehungen. Ergebnisse der ersten Welle des Beziehungs- und Familienpanels, Würzburg, 227-255

-/— (2012), Fertility From a Couple Perspective: A Test of Competing Decision Rules on Proceptive Behaviour, in: European Sociological Review 29, 535-548

Baykara-Krumme, H./D. Klaus/A. Steinbach (2011a), Eltern-Kind-Beziehungen in Einwandererfamilien aus der Türkei, in: Aus Politik und Zeitgeschichte 61, 42-49

-/_/_ (2011b), Generationenbeziehungen in Deutschland. Ein Vergleich der Beziehungsqualität in einheimischen deutschen Familien, Familien mit türkischem Migrationshintergrund und Aussiedlerfamilien, in: Brüderl, J./L. Castiglioni/N. Schumann (Hg.), Partnerschaft, Fertilität und intergenerationale Beziehungen. Ergebnisse der ersten Welle des Beziehungs- und Familienpanels, Würzburg, 259-286

Buhr, P./J. Huinink (2011), Armut im Kontext von Partnerschaft und Familie, in: Berger, P. A./K. Hank/A. Tölke (Hg.), Reproduktion von Ungleichheit durch Arbeit und Familie, Wiesbaden, 201-233

-/_ (2012), Die Bedeutung familienpolitischer Maßnahmen für die Entscheidung zum Kind, in: Zeitschrift für Sozialreform 58, 315-341

—_/ M. Boehnke/K. Maul (2011), Kinder oder keine? Institutionelle Rahmenbedingungen und biographische Voraussetzungen für die Familiengründung und -erweiterung in Ost- und Westdeutschland, in: Brüderl, J./L. Castiglioni/N. Schumann (Hg.), Partnerschaft, Fertilität und intergenerationale Beziehungen. Ergebnisse der ersten Welle des Beziehungs- und Familienpanels, Würzburg, 175-201

-/A.-K. Kuhnt (2012), Die kurzfristige Stabilität des Kinderwunsches von Kinderlosen in Ost- und Westdeutschland: Eine Analyse mit den ersten beiden Wellen des deutschen Beziehungs- und Familienpanels, in: Huinink, J./M. Kreyenfeld/H. Trappe (Hg.), Familie und Partnerschaft in Ost- und Westdeutschland. Ähnlich und doch immer noch anders, Leverkusen, 275-297 
Diener, K./M. Feldhaus (2011), 'Hartz' oder Herz? Hartz IV und die Intention zum Zusammenziehen in Partnerschaften, in: Zeitschrift für Sozialreform 57, 199-220

Dorbritz, J./A. Manthe (2012), Zum Einfluss der Lebensform und des sozialen Umfelds auf den Kinderwunsch, in: Bevölkerungsforschung Aktuell 33, 8-15

-/R. Naderi (2012), Stability of Bilocal Relationships - Conditions and Development Paths. An Analysis of the First and Second Wave of Pairfam, in: Comparative Population Studies 37, 429-462

Feldhaus, M./J. Huinink (2011), Multiple Elternschaften in Deutschland - eine Analyse zur Vielfalt von Elternschaft in Folgepartnerschaften, in: Schwab, D./L. A. Vaskovics (Hg.), Pluralisierung der Elternschaft und Kindschaft. Familienrecht, soziologie und -psychologie im Dialog, Leverkusen, 77-104

-/M. Schlegel (2011), Einflüsse der Partnerschaftsdynamik auf den Übergang zur Kohabitation und zur Heirat, in: Brüderl, J./L. Castiglioni/N. Schumann (Hg.), Partnerschaft, Fertilität und intergenerationale Beziehungen. Ergebnisse der ersten Welle des Beziehungs- und Familienpanels, Würzburg, 73-103

Häring, A./T. Klein/J. Stauder/A. Woll (2011), Partnermarkt und Suchverhalten von Singles in Deutschland, in: Brüderl, J./L. Castiglioni/N. Schumann (Hg.), Partnerschaft, Fertilität und intergenerationale Beziehungen. Ergebnisse der ersten Welle des Beziehungs- und Familienpanels, Würzburg, 49-72

Hillmann, J. (2012), Wann wollen zwei das Gleiche? Eine Analyse der Elternschaftsabsichten von Paaren auf Grundlage der 1. Welle des Beziehungs- und Familienentwicklungspanels (pairfam), in: DGD-Online-Publikation 1, 116-121

Hubert, S. (2011), Die Effekte von Religion auf die Kinderzahl, in: Brüderl, J./L. Castiglioni/N. Schumann (Hg.), Partnerschaft, Fertilität und intergenerationale Beziehungen. Ergebnisse der ersten Welle des Beziehungs- und Familienpanels, Würzburg, 203-226

Huinink, J./J. Brüderl/B. Nauck/S. Walper/L. Castiglioni/M. Feldhaus (2011), Panel Analysis of Intimate Relationships and Family Dynamics (pairfam): Conceptual Framework and Design, in: Zeitschrift für Familienforschung 23, 77-101

-/M. Feldhaus (2012), Fertility and Commuting Behaviour in Germany, in: Comparative Population Studies 37, 491-516

Hutteman, R./W. Bleidorn/L. Penke/J. J. A. Denissen (2012), It Takes Two: A Longitudinal Dyadic Study on Predictors of Fertility Outcomes, in: Journal of Personality, Early View, 5 Feb 2013, 1-12

Klaus, D./B. Nauck/A. Steinbach (2012), Relationships to Stepfathers and Biological Fathers in Adulthood: Complementary, Substitutional, or Neglected?, in: Advances in Life Course Research 17, 156-167

Konietzka, D./A. Tatjes (2012), Werden junge Menschen immer später erwachsen? Der Auszug aus dem Elternhaus, die erste Paarbeziehung und die erste Lebensgemeinschaft in Ost- und Westdeutschland, in: Huinink, J./M. Kreyenfeld/H. Trappe (Hg.), Familie und Partnerschaft in Ost- und Westdeutschland. Ähnlich und doch immer noch anders, Leverkusen, 173-200

Kopp, J./D. Lois/C. Kunz/O. A. Becker (2010), Verliebt, verlobt, verheiratet. Institutionalisierungsprozesse in Partnerschaften, Wiesbaden

Kotte, M./V. Ludwig (2011), Intergenerational Transmission of Fertility Intentions and Behaviour in Germany: The Role of Contagion, in: Wiener Institut für Demographie der Österreichischen Akademie der Wissenschaften (Hg.), Vienna Yearbook of Population Research 2011, Bd. 9, Wien, 207-226 
Kreyenfeld, M./S. Bastin (2010), Nichteheliche Elternschaft, in: Goldstein, J. R./M. Kreyenfeld/J. Huinink/D. Konietzka/H. Trappe (Hg.), Familie und Partnerschaft in Ost- und Westdeutschland. Ergebnisse des Projekts „Demographic Differences of Life Course Dynamics in Eastern and Western Germany", Rostock, 28

-/D. Konietzka/R. Walke (2011a), Dynamik und Determinanten nichtehelicher Mutterschaft in Ost- und Westdeutschland, in: Brüderl, J./L. Castiglioni/N. Schumann (Hg.), Partnerschaft, Fertilität und intergenerationale Beziehungen. Ergebnisse der ersten Welle des Beziehungs- und Familienpanels, Würzburg, 155-174

-/K. Zeman/M. Burkimsher/I. Jaschinski (2011b), Fertility Data for GermanSpeaking Countries: What is the Potential? Where are the Pitfalls?, in: Zeitschrift für Bevölkerungswissenschaft 36, 349-380

Lois, D./J. Kopp (2011), Elternschaftskonstellationen bei Alleinerziehenden, in: Schwab, D./L. A. Vaskovics (Hg.), Pluralisierung der Elternschaft und Kindschaft. Familienrecht, -soziologie und -psychologie im Dialog, Leverkusen, 59-76

—/N. Lois (2012), 'Living apart together' - eine dauerhafte Alternative? Zur Bedeutung von beruflichen Lagen und Partnerschaftsbildern für das Leben in getrennten Haushalten, in: Soziale Welt 63, 117-140

Lois, N. (2012), 'Living apart together': Sechs Typen einer heterogenen Lebensform, in: Zeitschrift für Familienforschung 24, 247-268

Mühling, T./J. Schreyer (2012), Beziehungsverläufe in West- und Ostdeutschland Stabilität und Übergänge, in: ifb Materialien 4, 1-77

Nauck, B./R. Tabuchi (2012), One or Two Pathways to Individual Modernity? The Effects of Education on Family Formation among Women in Japan and Germany, in: Vienna Yearbook of Population Research 10, 49-76

Nomaguchi, K. M./M. A. Milkie (2003), Costs and Rewards of Children: The Effects of Becoming a Parent on Adults' Lives, in: Journal of Marriage and Family 65, 356-374

Perelli-Harris, B./M. Kreyenfeld/W. Sigle-Rushton/R. Keizer/T. Lappegård/A. Jasilioniene et al. (2012), Changes in Union Status during the Transition to Parenthood in Eleven European Countries, 1970s to Early 2000s, in: Population Studies: A Journal of Demography 66, 167-182

- W. Sigle-Rushton/M. Kreyenfeld/T. Lappegård/R. Keizer/C. Berghammer (2010), The Educational Gradient of Childbearing within Cohabitation in Europe, in: Population and Development Review 36, 775-801

Pollmann-Schult, M. (2013), Parenthood and Life Satisfaction in Germany, in: Comparative Population Studies 38, 85-108

Rainer, H./I. Smith (2012), Education, Communication and Wellbeing: An Application to Sexual Satisfaction, in: Kyklos - International Review for Social Sciences 65, $581-598$

Richter, N./D. Lois/O. Arránz Becker/J. Kopp (2012), Mechanismen des Netzwerkeinflusses auf Fertilitätsentscheidungen in Ost- und Westdeutschland, in: Huinink, J./M. Kreyenfeld/H. Trappe (Hg.), Familie und Partnerschaft in Ost- und Westdeutschland. Ähnlich und doch immer noch anders, Leverkusen, 95-118

Ruckdeschel, K. (2004), Determinanten des Kinderwunsches in Deutschland, in: Zeitschrift für Bevölkerungswissenschaft 29, 363-386

Rüger, H./M. Feldhaus/K. S. Becker/M. Schlegel (2011), Zirkuläre berufsbezogene Mobilität in Deutschland: Vergleichende Analysen mit zwei repräsentativen Surveys zu Formen, Verbreitung und Relevanz im Kontext der Partnerschafts- und Familienentwicklung, in: Zeitschrift für Bevölkerungswissenschaft 36, 193-220 
Salzburger, V./R. Walke (2010), Der Zusammenzug mit dem Partner, in: Goldstein, J. R./M. Kreyenfeld/J. Huinink/D. Konietzka/H. Trappe (Hg.), Familie und Partnerschaft in Ost- und Westdeutschland. Ergebnisse des Projekts „Demographic Differences of Life Course Dynamics in Eastern and Western Germany", Rostock, 26

Schmahl, F./A. Langmeyer/M. Schaer/E.-V. Wendt/C. Thönnissen/S. Walper (2011), Effekte von feindseligen Attributionen und Konfliktstilen auf die subjektive Stabilität von Paarbeziehungen, in: Brüderl, J./L. Castiglioni/N. Schumann (Hg.), Partnerschaft, Fertilität und intergenerationale Beziehungen. Ergebnisse der ersten Welle des Beziehungs- und Familienpanels, Würzburg, 125-151

-/S. Walper (2012), Can You Relate? The Importance of Need Satisfaction for the Quality and Progressive Union Formation Process of Intimate Relationships, in: Comparative population studies 37, 361-392

Schmitz, A./S. Sachse-Thürer/D. Zillmann/H.-P. Blossfeld (2011), Myths and Facts about Online Mate Choice: Contemporary Beliefs and Empirical Findings, in: Zeitschrift für Familienforschung 23, 358-381

Schnor, C. (2012), Trennungsrisiko von Paaren mit Kindern: Der Einfluss der Religion in West- und Ostdeutschland, in: Huinink, J./M. Kreyenfeld/H. Trappe (Hg.), Familie und Partnerschaft in Ost- und Westdeutschland. Ähnlich und doch immer noch anders, Leverkusen, 229-256

Skopek, J./F. Schulz/H.-P. Blossfeld (2009), Partnersuche im Internet, in: Kölner Zeitschrift für Soziologie und Sozialpsychologie 61, 183-210

Smith, I. (2012), Reinterpreting the Economics of Extramarital Affairs, in: Review of Economics of the Household 10, 319-343

Steinbach, A. (2008), Stieffamilien in Deutschland, in: Zeitschrift für Bevölkerungswissenschaft $33,153-180$

Tatjes, A./D. Konietzka (2010), Die erste Paarbeziehung, in: Goldstein, J. R./M. Kreyenfeld/J. Huinink/D. Konietzka/H. Trappe (Hg.), Familie und Partnerschaft in Ost- und Westdeutschland. Ergebnisse des Projekts „Demographic Differences of Life Course Dynamics in Eastern and Western Germany", Rostock, 24-25

Uhlendorff, H. (2003), Großeltern und Enkelkinder: Sozialwissenschaftliche Perspektiven und Forschungsergebnisse hinsichtlich einer selten untersuchten Beziehung, in: Psychologie in Erziehung und Unterricht 50, 111-128 


\section{Appendix}

\begin{tabular}{|c|c|c|c|}
\hline 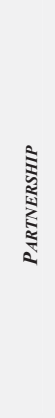 & $\begin{array}{l}\text { Value of Partnership Institutionalization } \\
\text { - partnership events } \\
\text { - plans for the future } \\
\text { - ambivalences in decision making } \\
\text { Framing: Cognitive-Emotional } \\
\text { Dispositions } \\
\text { - commitment } \\
\text { - reciprocity orientation } \\
\text { - readiness to make sacrifices } \\
\text { - hostile attributions } \\
\text { - forgiveness } \\
\text { - feelings of competence in the partner- } \\
\text { ship } \\
\text { (In-)Stability of Partnership }\end{array}$ & $\begin{array}{l}\text { Sexuality } \\
\text { - first kiss, first petting, first sexual inter- } \\
\text { course } \\
\text { - frequency of sexual intercourse } \\
\text { - satisfaction with sex life } \\
\text { - sexual competence } \\
\text { Partnership Quality } \\
\text { - satisfaction } \\
\text { - intimacy } \\
\text { - conflicts } \\
\text { - esteem } \\
\text { - autonomy } \\
\text { - ambivalence } \\
\text { - fear of love withdrawal } \\
\text { - engulfment anxiety }\end{array}$ & $\begin{array}{l}\text { Adaptive Processes } \\
\text { - Conflict styles (self/partner) } \\
\text { - constructive behavior } \\
\text { - verbal aggression } \\
\text { - withdrawal } \\
\text { - manipulation } \\
\text { - areas of conflicts } \\
\text { - dyadic coping (self/partner) } \\
\text { Potential Problems in Partnership } \\
\text { - infidelity } \\
\text { - violence } \\
\text { - alcohol and drug problems } \\
\text { Role Allocation } \\
\text { - division of labor } \\
\text { - fairness of division of labor } \\
\text { - dominance }\end{array}$ \\
\hline 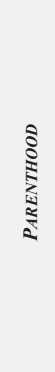 & $\begin{array}{l}\text { Childbirths } \\
\text { Proximal factors } \\
\text { - contraception } \\
\text { - fertility } \\
\text { - pregnancy } \\
\text { - procreative behavior } \\
\text { - current pregnancy } \\
\text { - abortion } \\
\text { - miscarriage } \\
\text { - reproductive treatments } \\
\text { Partnership Context } \\
\text { - agreement with partner about the num- } \\
\text { - ber of children } \\
\text { - agreement with partner about timing }\end{array}$ & $\begin{array}{l}\text { Network Influences } \\
\text { - opinions of friends and parents about } \\
\text { - parenthood } \\
\text { - priority of occupational matters } \\
\text { - support given by individual environ- } \\
\text { ment } \\
\text { Welfare-State Conditions } \\
\text { - child-friendliness of society } \\
\text { - assessment of family policy } \\
\text { - assessment of possibility of having a } \\
\text { family and pursue a career } \\
\text { - influence and importance of family } \\
\text { policy }\end{array}$ & $\begin{array}{l}\text { Timing of Family Foundation and } \\
\text { Extension } \\
\text { - realistic age first/next child } \\
\text { - latest age first/next child } \\
\text { - prerequisites for parenthood } \\
\text { to cut back in other life domains } \\
\text { - decision making } \\
\text { - expectations about life with child(-ren) } \\
\text { - reasons against (further) children } \\
\text { Desire for Children } \\
\text { - ideal number of desired children } \\
\text { - realistic number of desired children } \\
\text { - parenthood intention within } 2 \text { years } \\
\text { - adoption intentions within } 2 \text { years }\end{array}$ \\
\hline 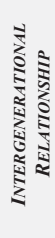 & $\begin{array}{l}\text { Values of Parents (VOP) } \\
\text { Values of Children (VOC) } \\
\text { Network of Relationship Inventory (NRI) } \\
\text { Structural Dimension } \\
\text { - demographic information } \\
\text { - travel-time distance } \\
\text { - move out of parent's home }\end{array}$ & $\begin{array}{l}\text { Affective Dimension } \\
\text { - emotional closeness } \\
\text { - intimacy } \\
\text { - conflicts } \\
\text { - ambivalence } \\
\text { Functional Dimension } \\
\text { - need for care } \\
\text { - given support } \\
\text { - received support }\end{array}$ & $\begin{array}{l}\text { Associative Dimension } \\
\text { - frequency of contact } \\
\text { - leisure activities } \\
\text { - intergenerational esteem } \\
\text { - assertiveness } \\
\text { Normative Dimension } \\
\text { - family norms } \\
\text { - intergenerational duties } \\
\text { - importance of grandparenthood }\end{array}$ \\
\hline 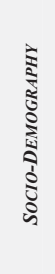 & $\begin{array}{l}\text { Education and Employment } \\
\text { - educational certificates } \\
\text { - activity status (education, employment, } \\
\text { unemployment, inactivity) } \\
\text { - occupational status } \\
\text { - labor contract, working time (regula- } \\
\text { tions), commuting, stress } \\
\text { - assessment of the chances on the labor } \\
\text { market } \\
\text { - educational and occupational career } \\
\text { since the age of } 18 \text { (retrospective) }\end{array}$ & $\begin{array}{l}\text { Income and Social Benefits } \\
\text { Place of Residence und Living } \\
\text { Arrangements Migration Background } \\
\text { Religiosity } \\
\text { Health } \\
\text { - health status } \\
\text { - body height, weight (BMI) } \\
\text { - reduction in earning capacity, disability } \\
\text { - sleep duration }\end{array}$ & $\begin{array}{l}\text { Network Connection } \\
\text { - sharing personal thoughts and feelings } \\
\text { - regular meetings for activities } \\
\text { - help with information or advice in prac- } \\
\text { tical matters } \\
\text { - occasional quarrels or conflicts } \\
\text { Leisure Activities } \\
\text { - with and without partner } \\
\text { Life-History-Calendar } \\
\text { - events between the waves }\end{array}$ \\
\hline
\end{tabular}

Figure 2: Instruments 
